\title{
De tempos y reflejos especulares: los Ensayos imaginarios de Sonia Rangel
}

\author{
Elsa Torres Garza
}

\author{
Sonia Rangel, Ensayos imaginarios. Aproximaciones estéticas \\ al cine de David Lynch, David Cronenberg, Béla Tarr \\ y Nicolás Pereda. México, Itaca, 2015. 194 pp.
}

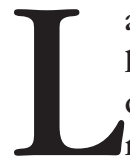

a metódica aproximación a la obra cinematográfica en general que ha emprendido Sonia Rangel habla, por supuesto, de un largo aprendizaje en el arte de mirar, que reporta una continua recreación y un renovado, activo, refinamiento en su aplicada y gozosa - una cosa no quita la otra- experiencia en el encantado mundo de la cinefilia. Si a este saber hecho de apreciación, curiosidad y documentación, agregamos su formación filosófica profesada con no menor gozo y rigor intelectual, tenemos entonces dos entrecruzados haces de luz con los que Sonia construye un artilugio lumínico: el presente libro, en el que la filosofía captura el incesante destello de la imagen cinematográfica.

Una cosa debemos reconocer en este minucioso acercamiento filosófico al lenguaje cinematográfico: lo infrecuente en nuestras latitudes, me refiero a México en particular, estos Ensayos imaginarios de Sonia Rangel constituyen una rica aportación al ejercicio de pensar con el cine y a la transmisión de una proteica experiencia, no exenta de aventura y desafío, que la autora vive ante la pantalla cinematográfica.

A partir de las obras del filósofo galo Guilles Deleuze y en especial de las que dedica al cine: Imagen-movimiento e Imagen-tiempo (y empapada de su léxico), Sonia realiza un recorrido exhaustivo en la producción de cuatro cineastas contemporáneos, portando como piedra de toque la imagen-cine, articulada en algunos "conceptos operativos" que definen el tipo de imagen que a su vez caracteriza el tratamiento de la imagen en cada uno de ellos. Se trata de David Lynch, David Cronenberg, Béla Tarr y Nicolás Pereda, todos ellos indudables espagíricos de la imagen-cine.

David Lynch, afinado en la pintura, el folletín televisivo y la música, es uno de los cineastas más polifacéticos del cine estadounidense, comenzó su trayectoria realizando trabajos inclasificables y perturbadores. Al recordar Eraserhead las imágenes aún persisten como sorprendentes por la secuencia 
de imágenes fractales definidas como "realidad puramente virtual, la que no se encadena sino que desencadena efectos al conectarse a otras imágenes de manera aleatoria dando lugar a una serie de imágenes fractales" (p. 17), creando una historia en la que el delirio y la realidad se mezclan en ambientes reales e irreales, ambos opresivos y cruzados por escenas surgidas del absurdo, o como dice Sonia, de non sense cuya tradición en el género es proverbial en la literatura inglesa, basta recordar a Lewis Carrol o a Edward Lear. La imagen fractal, la que nos remite a lo que Deleuze llama la imagen cristal, es el momento que en el transcurso de las imágenes fílmicas la imagen virtual y la imagen real se confrontan como en un espejo, cristalizando la imagen en su carácter indiscernible. Sin dejar de nutrirse de Deleuze, Sonia Rangel anota: "Lo virtual no se opone a lo real, mientras que lo virtual se opone a lo actual. La realidad de lo virtual acontece en series de relaciones diferenciales, así como en la distribución de singularidades" (idem). Estas imágenes fractales son producidas en el cine de Lynch mediante el uso de imágenes electrónico-digitales que permiten una reversibilidad y, según Lynch, crean un "nuevo automatismo", un montaje aleatorio, por contraste con la imagen analógica. Según Deleuze, la imagen-fractal se vuelve legible cuando es liberada del sonido, resultando entonces que el sonido y lo visual se vuelven irreductibles el uno al otro, recurso que permite el surgimiento de nuevas sensaciones, nuevos escalofríos.

Cito a Lynch: "Para mí las fábricas son símbolos de la creación con los mismos procesos orgánicos que hay en la naturaleza”. El cuerpo humano es visto como un mecanismo que produce, reproduce y desea; análogamente la máquina como organismo, como "cuerpo sin órganos", como un proceso de expansión y expresión, como intensidad cerrada; según Deleuze: "El cuerpo sin órganos es un cuerpo afectivo, intensivo, anarquista, que sólo comporta polos, zonas, ambientes y gradientes. Una poderosa vitalidad no orgánica lo atraviesa". Sonia ve en esa cita el drama de John Merrick, el hombre elefante, en cuya biografía se basó Lynch para hacer una película. En efecto, el cuerpo de Merrick, invadido y transfigurado en un fenómeno (freak) por una enfermedad, lo reduce a la imposibilidad de vivir en sociedad, aislado y acechado, inerme y malamente protegido, encontrará lo que llama Sonia una "línea de fuga", una articulación hacia el mundo, en su relación galante con una dama protectora y en otra instancia como constructor de maquetas.

He entresacado apenas unas nociones del ensayo sobre Lynch de Sonia, no puede ser de otro modo, pues su discurso está trabado de tal forma que resulta imposible seguirlo en toda su extensión sin detenerse en todas y cada una de sus frases. No sólo con el ensayo de Lynch, sino que el mismo comentario vale para todo el libro.

Imagen-maquínica. Devenires e intensidades en el cine de David Cronenberg, es el título del ensayo imaginario correspondiente al cineasta canadiense. A 
Cronenberg le obsesiona el tema del cuerpo y su relación con las máquinas, más precisamente el horror corporal, el cuerpo como enfermedad. Una "maquina deseante" que se evoca con facilidad por la impresión causada en la memoria es la transformación de la máquina de escribir en insecto gigantesco mientras William Lee escribe en ella situado en la Interzona, un mundo virtual inducido por las drogas en The Naked Lunch, película de título homónimo de la novela de Burroughs. (El interés de Cronenberg por la literatura es claro, pues incluso se graduó en Letras en La Universidad de Toronto.) Y así en sus otros filmes se establecen relaciones de (cito a Sonia) "series intensivas"

[...] del cuerpo que se inter-relacionan, cruzan y se conectan entre sí, series de transformación ya sea orgánica (virus-enfermedad) o tecnológica (intervención) que se expresan en la serie del cuerpo protésico. Dicha serie es efecto de la incorporación de la tecnología que Cronenberg explora en filmes como Videodrome (televisión), Crash (automóvil) y Existenz (juego de video), y el cuerpo intervenido, explorada en filmes como La mosca (modificación molecular), Naked Lunch (droga), Promesas del Este (tatuaje). Estas series operan liberando flujos maquínicos, devenires a través de los cuales se rompe la organización de los cuerpos.

Cambia el concepto de cuerpo, éste no se encuentra disociado con la mente, la mente se materializa y el cuerpo deviene en pensamiento. Cuerpos y mentes son máquinas experimentales de sensaciones. Las historias se convierten en devenires, en flujos mentales, sensoriales, afectivos.

Un punto en común de todos los escritores tratados aquí es el de la creación de mundos paralelos, de zonas virtuales de la realidad resignificada o excluida hasta el absurdo y genéricamente llamada "la zona" o "interzona". Éste es un aspecto reiterado en el cine de autor desde un principio y hasta la fecha continuamente reelaborado.

La imagen-tiempo corresponde al cineasta húngaro Béla Tarr, el tiempo circular, el tiempo que retorna abolido del presente, en un fluir originario, incesante del pasado hacia el futuro, que congela el instante, en el que presenciamos seres humanos y cosas como fantasmas, como seres distanciados unos de otros en un reconocimiento semi-animal, co-ausente, así como en Armonías de Werckmeister, en el momento en que arriba a la plaza el circo con su monstruo, una ballena gigante disecada que pasean como atracción dudosa, en el que el abnegado y estudioso de los astros Janoz, instantes antes de comprar su boleto para ver el fenómeno dirige su azorada mirada entre la multitud de viejos, todos hombres, obreros tal vez, que como meras presencias miran con rostro duro hacia Janoz y hacia la nada, como una recriminación 
encarnada de una época totalitaria que sólo ha dejado duros despojos presagiando un desastre mayor, existencial, latente, cósmico en el ojo de la ballena, cristal muerto y punto de convergencia del tiempo circular. No puedo dejar de citar como lo expresa Sonia:

Así, la primera secuencia es una puesta en escena de la armonía de las esferas, la danza de los cuerpos celestes; coreografía montada y dirigida por Janoz, puesta en escena del movimiento inmemorial del sol, la luna y la tierra, continuum sideral-sonoro que es trastocado por un eclipse, forma del des-astre, silencio sonoro infinito que sumerge a la tierra en la oscuridad impenetrable, efecto de la detención del movimiento del Mundo. El des-astre es un contra-tiempo sin presente, un tiempo flotante, que desencadena el desplome del espacio y el tiempo cotidianos.

Plano seguido se inicia un desplazamiento nocturno del gran contenedor que porta a la ballena, que en su lentísimo movimiento va creando un escenario de luces y sombras en analogía con la "danza de las esferas" que como una coreografía puso en escena Janoz a pedido de los parroquianos de una taberna usándolos como astros. Luces y sombras largas, preludios y codas sin fin, un movimiento perpetuo que finaliza sin alcanzar a la vida.

De aquí que Sonia Rangel vea desplegarse en los filmes descontextuados y metafóricos de Béla Tarr, quien en algún momento pretendió ser filósofo, la potencia repetitiva del ritornelo, que "es la forma en la que el tiempo se vuelve sonoro [...] es la construcción y operación de una imagen sonora, forma del tiempo fílmico: internal (interno-eterno), que a la vez es la melancolía de lo que vuelve a caer en el pasado y su posible repetición como potencia afectiva". Agotamiento, fatiga, acidia, todo ello revelan los movimientos lerdos, parsimoniosos de la cámara de Béla Tarr, al tiempo que la banda sonora marca los tiempos de la disolución.

Nicolás Pereda es un director de cine mexicano que ha sabido emplear con destreza las herramientas y el legado teórico-conceptual, así como una envidiable asimilación intuitiva del cine de autor. Para él esta categoría pertenece a lo experimental. El propio Pereda considera que sus cintas difícilmente podrían llegar a un público más amplio, habituado como está a los enfoques sociológicos que imperan en el cine nacional. Sonia Rangel destaca, para el caso de este cineasta, la potencia de la imagen-repetición y el ensamble con la des-dramatización y la ficción. Aderezando su ensayo con entrevistas a Pereda, realizadas por ella y Amiel Martínez, se confirman los conceptos operatorios que ve accionados en la filmografía de Pereda, a saber, los ya mencionados arriba, el ritornelo y la perspectiva barroca. No mencionaré aquí las películas analizadas, sólo referiré que se recomienda verlas una por 
una en sentido cronológico, pues Pereda, además de trabajar con los mismos actores (que siempre actúan con su propio nombre), siempre incluye metáforas o referentes expresivos de su película anterior. Sólo quisiera mencionar como un último comentario que en el cine de Pereda se advierten los efectos de la imagen-desafección que encontramos en el cine de Béla Tarr, como la no-acción, la apatía y la apraxia. El propio Pereda no niega la influencia del húngaro en sus dispositivos cinematográficos, además de la de otros grandes directores como Abbas Kiarostami, Tsai Ming-liang, último en quien pensaba mientras rodaba Juntos. Cabe decir que Nicolás Pereda es una rara avis de nuestra cinematografía.

Para concluir sólo quisiera felicitar a la autora por este magnífico libro, probablemente el primero de una larga lista de títulos futuros que, sin duda alguna, serán tan sorpresivos e interesantes como estos Ensayos imaginarios, legítimas joyas para la theoria del cine. 